\title{
IMPACT OF PSYCHOLOGICAL CHARACTERISTICS ON THE BUSINESS PERFORMANCE OF MUSLIM WOMEN ENTREPRENEURS IN SRI LANKA
}

\author{
M. A. C. Salfiya Ummah \\ South Eastern University of Sri Lanka, Sri Lanka, salfiyau@seu.ac.lk
}

\begin{abstract}
Women entrepreneurship is a highly stressful initiative which requires mental efforts related to psychological characteristics. In some Islamic families, women are less empowered, as their mobility is constrained and certain traditions and values observed by society affect their achievement in business. Therefore, this study aims to investigate the effects of several psychological capital (PC) factors on the business performance (BP) of Muslim women entrepreneurs (MWEs) in Sri Lanka. The measurement of PC entails the factors of need for achievement (NA), risk taking (RT), internal locus of control (ILC), and independent motives (IM). Data were collected using a structured questionnaire; the study sample involved 260 MWEs from Sri Lanka's Eastern Province selected via the simple random sampling technique. The structural equation modeling (SEM) method with AMOS was used to test the proposed hypotheses. The findings show that only RT had a significant and positive impact on BP, whereas NA, ILC, and IM did not significantly influence the BP of MWEs in Sri Lanka. In short, those who were risk takers were able to make positive achievements in their business ventures. The study findings provide evidence of the significance of family members, spouses and social stigma on MWEs' psychological state and ultimately their business performance.
\end{abstract}

Keywords: Psychological characteristics, Need for achievement, Risk taking, Internal locus of control, Independent motives.

JEL classification: L26; C12; G41.

Article history:

Received : October 7, 2020

Revised : March 9, 2021

Accepted : June 24, 2021

Available online : November 30, 2021

https://doi.org/10.21098/jimf.v7i4.1380 


\section{INTRODUCTION}

\subsection{Background}

Entrepreneurship has been defined as an innovative effort to exploit business prospects (Schumpeter, Clemence, \& Swedberg, 2017). Entrepreneurs are individuals with the capacity and mindset for starting and operating a business with the aim of generating a profit (Machmud \& Ahman, 2019). There is growing research on the role of religion in forming entrepreneurial approaches and levels in different societies. In Islam, entrepreneurship is part of the way of life. Machmud \& Hidayat (2020) proposed a holistic entrepreneurial approach underpinned by religion; they assert that the teachings of Islam provide theoretical and practical support for entrepreneurship. Religion is central in Muslim life. In recent years, various forums such as the World Islamic Economic Forum (WIFE), Organization of Islamic Cooperation (OIC), Islamic Centre for Development of Trade (ICDT), Islamic Cooperation Youth Forum (ICYF) and the Global Islamic Economic Summit have focused on enhancing awareness of Islamic economics and empowering both men and woman Muslimpreneurs. Business activities are encouraged in Islam as a way to improve one's social and economic situation; the religion asserts that nine out of ten livelihood sources are derived from industry and entrepreneurship (Rekarti, Bahari, Zahari, Doktoralina, \& Ilias, 2019). Allah SWT decreed in Sura An-Nisa (4:29) in the Al-Quran that trade and commerce make up a part of a believer's worship to Him. Women in Islam are not prohibited from engaging in business activities. They are in fact given complete rights to venture into entrepreneurship, while being mindful of the rules which safeguard them from harm (Ullah, Mahmud, \& Yousuf, 2013).

Islamic principles in entrepreneurial activities are taken from Al-Quran and Al-Hadits. In Islam, entrepreneurship must be underpinned by taqwa (faith) and worship to Allah the Almighty. Islamic economics must also be complemented by the concepts of halal, efficacy, nobility, honesty, prosperity, and pure concern for the well-being of society and the surrounding environment (Machmud \& Ahman, 2019). Entrepreneurship in Islam has also been developed based on the principles of al-iman (belief), al-ilm (knowledge) and al-amal (piousness and initiative) (Abdullah \& Sahad, 2016). The actions of entrepreneurs in Islam are constantly in line with the principles and values emphasised in Islam (Machmud \& Hidayat, 2020).

As a main economic and social driver, entrepreneurship provides great opportunities for women. Recent decades have witnessed increased research attention on the topic of women entrepreneurship worldwide. This is mainly driven by the significant growth in the number of female-owned businesses and their impact on economic development, innovative efforts and job creation in numerous developed nations in the past decade (Mustapha \& Subramaniam, 2016). Currently, women are involved in various fields of work, including information and technology, engineering, and trade and industry, while also developing business ventures and contributing to national growth. Muslim women make a significant contribution to economic prosperity (Hammawa \& Norashidah, 2016). The Messenger of Allah, Prophet Muhammad PBUH, cared deeply for society and encouraged women to engage in entrepreneurship in order to improve the female community in general. Katheeja Raliyallahu Anha, who was the first wife of the 
Prophet Muhammed, was an exemplary businesswoman for all Muslim women. However, some Muslim societies deem women to be merely homemakers, with men as the sole providers.

Research on Muslim female entrepreneurship is vital and relevant, as Muslim women entrepreneurs have distinct motivations and objectives compared to their non-Muslim counterparts; for example, they need to uphold their faith and belief at all times as a pre-condition of effective business management (Ilhaamie, 2017). Previous research had highlighted several business drawbacks which hinder the progress of Muslim women entrepreneurs (Akhter \& Sobhani, 2016; Ilhaamie, Arni, Rosmawani \& Al-Banna, 2014; Kargwell, 2012). In some conservative Muslim communities, female children are prohibited from going out and mixing with their counterparts (Azam Roomi \& Harrison, 2010). This inevitably influences their personality characteristics when, for example, facing challenges, making decisions, and taking risks. Understanding the value of psychological characteristics, often referred to as personality characteristics/traits, has become an important research agenda in social science, as psychological characteristics influence Muslim women entrepreneurs' ability to enhance their business performance.

In the context of Sri Lanka, Muslim women entrepreneurs only own $7 \%$ of the businesses in the country based on the District Chambers Report during 2017 in Sri Lanka, indicating that Muslim women entrepreneurs are under-utilised compared to their male counterparts, who constitute the largest proportion of business owners (97\%). The Muslim community in particular adheres to certain traditions and values which are likely to influence their behaviour (Faizal, Ridhwan, \& Kalsom, 2013). In most Muslim families in Sri Lanka, children are instilled with certain values and beliefs which continue to influence their decision-making processes in adulthood. In short, Muslim women have limited opportunities to engage in entrepreneurship or decision-making. Similarly, in some families, social mobility is limited, thus creating an atmosphere in which women find it difficult to leave their homes and to network with their peers, business associates and trader associations, and may be unable to seek access to financing and other sources.

The general progress of Muslim women in Sri Lanka is often hindered by strict familial beliefs and traditions (Panda, 2018), which in turn affect the performance of Muslim women entrepreneurs in the country. Hence, there is a need to study the effect of psychological characteristics on the performance of MWEs in Sri Lanka. Therefore, interpreting the performance of Muslim women entrepreneurs has become a critical academic issue. Previous findings have posited psychological characteristics as an input for enhancing business performance (Gustomo, Ghina, Anggadwita, \& Herliana, 2019; Tri Ramdhani \& Anggadwita, 2016). However, these studies only focused qualitatively and in a limited way on identifying the psychological characteristics, with no empirical support for this in relation to the performance of Muslim women entrepreneurs in Sri Lanka. In addition, in some Muslim families, female children are forced to marry early rather than continuing their education to a higher level. Ibidunni et al. (2018) speculated that educational background is essential for business improvement. However, the moderating effect of education level on the relationship between the psychological characteristics and business performance has not been established, especially among Muslim women entrepreneurs. 
Therefore, the moderating impact on the relationship between psychological factors and the business performance of Muslim women entrepreneurs is paramount in researching Muslim women entrepreneurship. This leaves a significant research gap in the literature which needs to be addressed.

\subsection{Objective}

Studies on Muslim women entrepreneurs have also identified unique challenges, such as socio-cultural barriers in Indonesia (Anggadwita, Luturlean, Ramadani, \& Ratten, 2017); industrial barriers in Oman (Al-Sadi, Belwal \& Al-Badi, 2011); religious barriers in Bangladesh (Islam, Khan, Obaidullah, \& Alam, 2011); access to capital and governmental support in Bahrain and Oman (Dechant \& Al Lamky, 2005), as well as personal and family issues in the UAE (Itani, Sidani \& Balbaki, 2009). The progress of Muslim women in Sri Lanka is often hindered by strict familial beliefs and traditions (Panda, 2018), which in turn limit their participation and performance in business. There is an urgent need to recognize the exact psychological factors that affect such performance, and the moderation effect of educational level of businesswomen in the country.

Therefore, the objective of this study is to examine the effects of psychological characteristics on the performance of Muslim women entrepreneurs in the context of Sri Lanka and the moderation effect of their educational experience. This leads to the formulation of the following research questions:

1. Do psychological characteristics significantly affect the business performance of Muslim women entrepreneurs in Sri Lanka?

2. Does educational level significantly moderate the relationship between psychological characteristics and the business performance of Muslim women entrepreneurs in Sri Lanka?

The findings are expected to explain the distinct characteristics that characterize the business performance of Muslim women entrepreneurs in order to improve the important issues that need attention; this in turn could increase the participation of Sri Lankan Muslim women in business ventures.

\subsection{Significance of the Study}

This study analyzed the literature on the entrepreneurship of Muslim women, and suggests steps that the government, policymakers and other related agencies could take to empower Muslim women through entrepreneurship to improve the country's socio-economic conditions and the well-being of their families.

Furthermore, the inclusion of a comprehensive set of variables using powerful statistical analysis allows the research to provide a broader picture of the factors affecting Muslim women entrepreneurs' business performance, thus contributing new knowledge to the topic. The findings could serve as inspiration for existing Muslim women entrepreneurs to tackle the challenges they face in achieving greater efficiency in industry by focusing on their psychological characteristics. If this initiative succeeds, it will not only lead to economic growth in Sri Lanka, but will also inspire more Muslim women to take part in entrepreneurship. The results could also help provide better support for family members and spouses, 
as well as helping to overcome the community's social stigma. They could also provide a more in-depth understanding of the roles of family members, spouses and social stigma in determining the success of women in business by enhancing their psychological characteristics.

Therefore, the study first focuses on the background of the topic, the research objectives and questions and the significance of the study. The subsequent sections present the literature review, the methodology used in the study, discussion of the findings and the conclusion, together with the practical and academic implications.

\section{LITERATURE REVIEW}

\subsection{Background Theory}

In Islam, entrepreneurship makes up part of the way of life, in which entrepreneurial activities and religion are intertwined. The characteristics and guiding principles of entrepreneurship in Islam is underpinned by the al-Quran and al-Hadiths. Many Muslims around the world are successful entrepreneurs, consistent with the teachings of Islam, which urge its followers to engage in innovative and entrepreneurial endeavours (Tri Ramdhani \& Anggadwita, 2016). Many studies have examined the role of gender and economic empowerment in advancing Islamic societies; a majority are politically- and sociologically-based, whilst others have focused more on the economic, developmental and management contexts (Asad Sadi \& Al-Ghazali, 2010; McIntosh \& Islam, 2010). In Islam, entrepreneurship is defined as an individual's actions in taking opportunities by optimizing available resources, which is consistent with the work ethics prescribed by the religion (Hammawa \& Norashidah, 2016). A Muslim's work ethic entails the attitude and conviction that the performance of a given work is beyond the attainment of selfglorification and a show of humanity; rather, it is a demonstration of righteousness in line with the principles of Islam, which elevates the follower's status as a servant of Allah who is truly trustworthy. Muslim entrepreneurs are guided by the principles of Islam, which as a whole frees them for having to justify their means. In short, Islam encourages believers to engage in entrepreneurship (Machmud \& Hidayat, 2020).

In Islam, economic activities are undertaken not only to achieve prosperity, but also to increase a believer's faith and piousness. Entrepreneurship is an essential aspect of the Islamic way of life; each entrepreneur is accountable for nurturing prosperity as a demonstration of their faith and good deeds. Islam measures success not only by the final outcomes, but also by the ways and means of achieving them. Islamic law underpins the regulation of conducting business as an act of worship. This entails ethical business management in decision-making processes and its general implementation. Islam teaches its believers to make commercial transactions according to Islamic laws instead of in tyrannical ways (Surah: Al- Nisa 4:29). Each individual can benefit from practicing the elements of Islamic spiritual intelligence, including in business. A Muslim entrepreneur can be successful by displaying personal integrity in performing their work; this will facilitate the individual to tackle any challenges, whilst protecting them from engaging in prohibited business practices that are against Shariah provisions 
(Anggadwita et al., 2017). A Muslim women entrepreneur must have the characteristics of takwa and tawakkal, remembrance and gratitude, to be successful.

Many Islamic laws honour and benefit women (Anggadwita, Mulyaningsih, Ramadani, \& Arwiyah, 2015). Rekarti et al. (2019) assert that both male and female entrepreneurs should uphold Islamic values in their entrepreneurial endeavours and that Islam does not prohibit women from working. In Islam, men and women are deemed as equals in many aspects, despite having varying areas and depths of responsibility. In fact, Prophet Muhammed (PBUH) addressed men and women together. Islam therefore deems women to be independent legal entities that can engage in business (Anggadwita et al., 2015). Female engagement in numerous entrepreneurial efforts has also empowered them psychologically.

\subsection{Previous Studies}

Numerous studies had examined the topic of business performance. Research on small and medium-sized enterprises (SMEs) has indicated the various growth stages of SMEs, known as lifecycles (Gupta, Guha, \& Krishnaswami, 2013). Growth is vital for enterprises (Machado, 2016) and delineates the changes in size throughout a specific period (Yadev, 2015). In short, growth essentially indicates whether or not an enterprise is thriving. Business performance is also referred to in terms of success, efficiency, and sustainability, amongst other aspects. Entrepreneurial actions are used to measure business performance, and are crucial in ascertaining success (Ahmad, Ahmad, Kahat, \& Mutaza, 2012). According to Islam et al. (2011), performance is the capacity of a firm to create satisfactory results and actions. The fact that Muslim women hold great potential is why governments and local communities need to work together to create an entrepreneurial-oriented society that can empower Muslim women and provide them with adequate mechanisms to succeed and prosper (Hammawa \& Norashidah, 2016).

Based on the literature, this study delineates the business performance of Muslim women entrepreneurs through the growth of sales, profits and net assets, as well as the number of employees, customers and products or services, over a minimum of three operating years. According to Zulkiffli (2014), objective or subjective measures are used to measure the success or performance of a business venture. This study uses subjective measures to measure the business performance of Muslim women entrepreneurs.

Some studies have focused on psychological characteristics and their effect on such performance. These characteristics can also be stated to be personal attributes. In fact, psychological characteristics and personal attributes have been used interchangeably in the literature (Rashid, Ngah, Mohamed, \& Mansor, 2015). They will support entrepreneurs to tackle challenges during uncertainty situations and to ensure sound decisions are made to achieve business accomplishment.

Consequently, personal attributes have been extensively analyzed in previous studies (Anggadwita \& Dhewanto, 2016; Baluku, Kikooma, Bantu, Onderi, \& Otto, 2019). Entrepreneurship is a highly stressful endeavor, entailing risk taking and heavy workloads, both of which require psychological capital (Baluku, Kikooma, Bantu, \&Otto, 2018). Since theliterature indicates that Muslim womenentrepreneurs face more exceptional issues than their non-Muslim counterparts, there emerges 
a need to investigate the effects of psychological characteristics on their business performance, specifically in the context of Sri Lanka. Some studies have suggested that personal factors stimulate the performance of female entrepreneurs in general (Baron, Franklin, \& Hmieleski, 2016). Tri Ramdhani \& Anggadwita (2016), who argue that the psychological factors that affect the activities of successful Muslim women entrepreneurs include risk taking and innovativeness, measured the need for achievement and locus of control using a case study of an event organizer, as a qualitative method to identify psychological characteristic factors in business success. However, their study fails to include independence or autonomy as psychological characteristics.

In addition, most of the studies of Sri Lanka concern businessmen (Fernando, 2006; Perera \& Budhadhasa, 1992); there are limited research on business performance in relation to women entrepreneurship (Dharmaratne, 2012; Ranasinghe, 2008). Few studies have been conducted on Muslim businesswomen. Hence, there is dearth of literature on Muslim entrepreneurship in Sri Lanka. The study of Tri Ramdhani \& Anggadwita (2016) used a qualitative method to identify psychological factors such as risk taking, need for achievement, and locus of control, using a case study. Hence, this study finds this gap and attempted to find the causal relationship quantitatively. In addition, Islam considers that women have equal rights to men. Therefore, independence was added as a new construct to the model used in this study. This study will consequently fill the existing research gap with the inclusion of a comprehensive set of variables and by assessing the moderating effect of educational level on the psychological factors affecting business performance. It uses a quantitative method with a powerful statistical analysis- SEM approach with AMOS, which allows it to provide a broader picture of the psychological factors affecting the business performance of Muslim women entrepreneurs which contributes new knowledge to Islamic entrepreneurship.

\section{METHODOLOGY}

\subsection{Data}

The data were collected using a structured questionnaire. A total of 260 respondents from three districts in the eastern part of Sri Lanka, namely Ampara, Batticaloa and Trincomalee, comprised the study sample, chosen via stratified random sampling. The data were collected during regular meetings and the collection period was nearly eight months. The samples were chosen based on the criteria that i) their business had been operating for over 3 years; and ii) they were listed with Chamber of Commerce in the above three districts in Sri Lanka.

\subsection{Model Development}

The conceptual framework of the study is based on theliterature review of numerous articles and journal papers. Religion plays a vital role in defining the psychological characteristics of Muslim women entrepreneurs (Tri Ramdhani \& Anggadwita, 2016). Furthermore, Rashid et al. (2015) contend that personal attributes such as the need for achievement, risk taking, locus of control, and independent motives are 
important drivers of the psychological characteristics which promote successful business ventures among Muslim women entrepreneurs.

Previous researchers have identified the need for achievement, risk taking and locus of control as the psychological characteristics which influence the activity of successful Muslim women entrepreneurs in countries such as Indonesia and Malaysia. Furthermore, most successful women entrepreneurs have also been found to possess a higher need for achievement compared to risk taking and locus of control (Fuad \& Bohari, 2011). In addition to those psychological factors, being independent in one's decisions and actions is one of the major factors behind women's decision to become entrepreneurs.

Therefore, it is expected that the psychological characteristics of the need for achievement, risk taking, internal locus of control and independent motives of Muslim women entrepreneurs in Sri Lanka will influence their business performance. Since educational level plays an important role in modifying behaviour, it is also expected that this will moderate the relationship between psychological characteristics and business performance. Hence, the research framework is framed as follows:

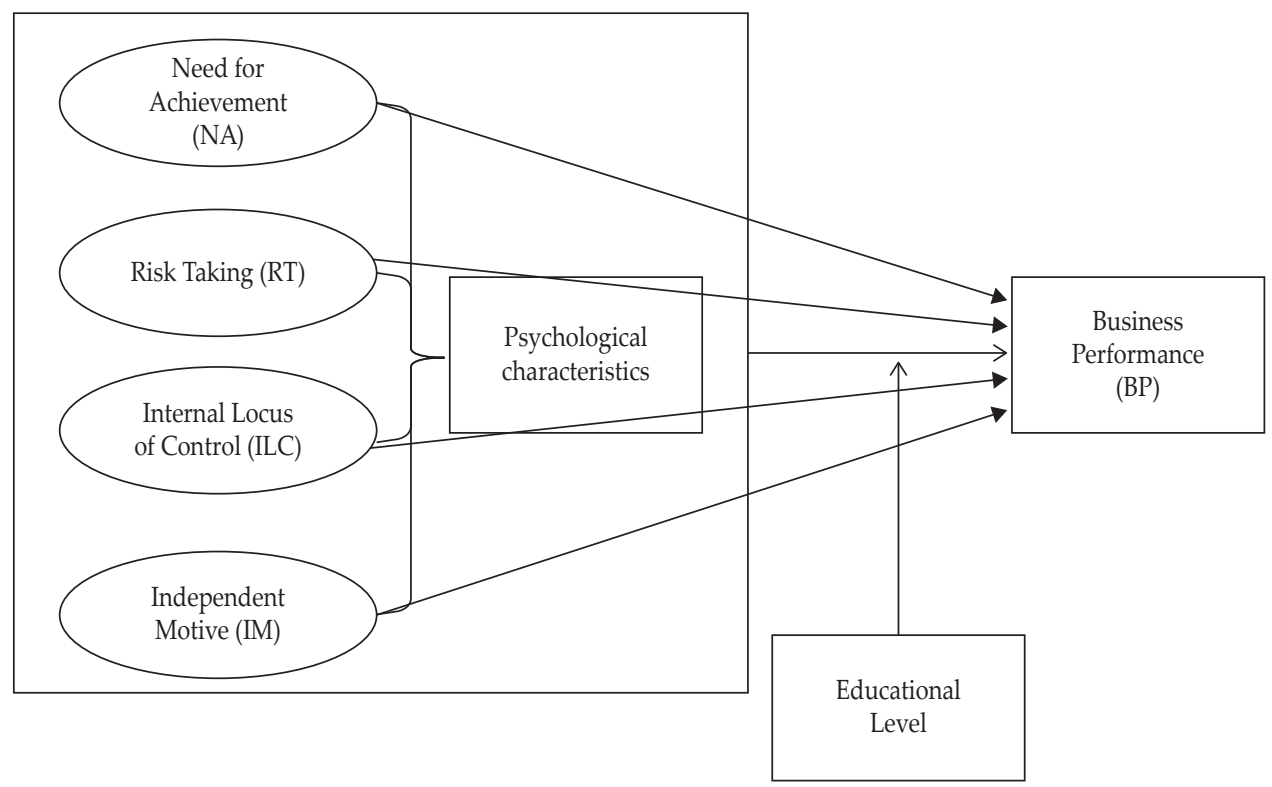

Figure 1.

Research Framework

The psychological characteristic constructs in this study compromise four latent variables: the need for achievement (NA), risk taking (RT), internal locus of control (ILC), and independent motives (IM). NA was operationalized with seven indicators such as 'I have the intention to achieve something in my life', 'I have the intention to create new business opportunities in my business', 'I set clear goals in my business', 'I set targets and evaluate the outcomes of my business 
activities', 'I want to achieve a better position in the society', 'I intend to increase sales revenue every year', My business venture should earn a good name from my customer'. (Anggadwita \& Dhewanto, 2016; Lerner, Brush, \& Hisrich, 1997). RT consisted of five indicators, such as'I take responsibility for all business-related activities', 'I avoid riba (interest) as one of my risks in my business operations', 'I am enthusiastic in doing things differently', 'I can face any challenge in my business', 'If I am frightened of something in my business, I will try to conquer that fear' while ILC had five indicators such as 'I work hard with maximum effort', 'I have enough self confidence in my initiative', 'I believe that my efforts will bring success to my business', 'I believe that I can enhance the living standards of my family through this business', 'I believe that I can enhance the living standards of my family through this business', based on Anggadwita \& Dhewanto, (2016). Finally, IM was also operationalized with five indicators, including 'My rewards are directly related to what I accomplish to $\mathrm{me}^{\prime}$, 'I prefer freedom in decision making', 'I have personal satisfaction of being an entrepreneur', I feel free to do something good for the society', 'I take my own decision in relation to employees' based on Lerner et al. (1997). Business performance consisted of six indicators to measure the concept, namely sales growth, profit growth, net assets, number of employees, number of new products, and number of customers (Walker \& Brown, 2004).

\section{The following hypotheses were derived:}

$\mathrm{H1}$ : The need for achievement significantly influences the business performance of Muslim women entrepreneurs in Sri Lanka.

H2: Risk taking significantly influences the business performance of Muslim women entrepreneurs in Sri Lanka.

H3: Internal locus of control significantly influences the business performance of Muslim women entrepreneurs in Sri Lanka.

H4: Independent motives significantly influence the business performance of Muslim women entrepreneurs in Sri Lanka.

H5: Educational level significantly moderates the relationship between the psychological characteristic dimensions (NA, RT, ILC, and IM) and the business performance of Muslim women entrepreneurs in Sri Lanka.

\subsection{Method}

This study used structural equation modeling (SEM) with AMOS to validate both the measurement and structural models in order to determine the effect of the psychological characteristics studied on the business performance of Muslim women entrepreneurs in Sri Lanka. In SEM, covariance structure analysis, partial least squares and generalized structural component analysis are used in the psychometric literature (Hwang et al., 2010). This study was based on covariancebased structural equation modeling (CB-SEM), since the model was correctly specified.

According to Byrne (2016) and Hair, Black, Barry, \& Anderson (2010), the study model can be validated using fit indices, namely the relative chi square, (CMIN/ 
$\mathrm{DF})$, the root mean square error of approximation (RMSEA) and one or two of the following: the goodness-of-fit index (GFI), adjusted goodness-of-fit index (AGFI), comparative-fit-index (CFI), normal-fit-index (NFI) and Turker-Lewis index (TLI). The relative chi-square should be lower than 5.0, while GFI, AGFI, CFI, IFI, NFI, and TLI must be over 0.90. Likewise, RMSEA and RMR should be lower than 0.08 to be considered as a good fit (Hair et al., 2010); researchers have suggested the use of at least three or four indices to ensure a model fit.

\section{RESULT AND ANALYSIS}

\subsection{Results}

\subsubsection{Profile of the respondents}

The study used frequency descriptions to analyze the respondents' demographic data, including their district where they lived, age, marital status, education level, business type, number of employees, experience, and whether their parent/s and/ or husband were entrepreneurs.

Table 1.

Profile of the Respondents

\begin{tabular}{lcc}
\hline Demographic Variable & Frequency & Percentage \\
\hline District & 98 & 37.7 \\
Ampara & 90 & 34.6 \\
Batticaloa & 72 & 27.7 \\
Trincomalee & & \\
\hline Age & 24 & 9.2 \\
Below 30 & 52 & 20.0 \\
31-40 & 114 & 43.9 \\
41-50 & 70 & 26.9 \\
Over 50 & & \\
\hline Marital Status & 139 & 53.5 \\
Married & 28 & 10.8 \\
Unmarried & 93 & 35.8 \\
Widowed/Divorced & & \\
\hline Education Level & 137 & 52.7 \\
Below G.C.E. (O/L) & 57 & 21.9 \\
G.C.E.(O/L) & 49 & 18.8 \\
G.C.E.(A/L) & 17 & 6.5 \\
Degree or above & & \\
\hline Business Type & 61 & 23.5 \\
Manufacturing & 40 & 15.4 \\
Craft \& arts & 65 & 25.0 \\
Services & 52 & 20.0 \\
Retail/Wholesale business & 42 & 16.1 \\
Agri-business & 0 & 0 \\
Other & &
\end{tabular}


Table 1.

Profile of the Respondents (Continued)

\begin{tabular}{lcc}
\hline Demographic Variable & Frequency & Percentage \\
\hline Number of Employees & & \\
Below 10 & 176 & 67.7 \\
$11-50$ & 75 & 28.9 \\
$51-200$ & 9 & 3.4 \\
\hline Business Experience & & \\
3-6 years & 32 & 12.3 \\
7-10 years & 138 & 53.1 \\
Over 10 years & 90 & 34.6 \\
\hline
\end{tabular}

Based on the data analysis, most of the respondents, i.e., 98 or $37.7 \%$, resided in the Ampara district, indicating that most of the Muslim population was concentrated in this district compared to the 25 other districts in Sri Lanka. In terms of age, most of the respondents, 114 or $43.9 \%$, were between 41 and 50 years old, indicating that most of the Muslim women entrepreneurs involved in business were aged over 40. More than half of the respondents, 139 (53.5\%), were married, demonstrating that married Muslim women engage in business in order to contribute to their family's livelihood. Similarly, more than half of the respondents, 137 (52.7\%), had attained a maximum of a GCE $(\mathrm{O} / \mathrm{L})$ education level, indicating that most of them chose to engage in business as an alternative to pursuing a higher education. In practice, Muslim families two or three decades ago preferred to marry off their children early instead of sending them away to further their studies. In terms of business type, the largest number of the women entrepreneurs, 65 or $25.0 \%$, chose to engage in the service industry, followed by the manufacturing industry at 61 $(23.5 \%)$. Most of the businesses owned by the Muslim women entrepreneurs, 176 $(67.7 \%)$, had fewer than 10 employees, indicating that a majority of the businesses were owned and were operating at the micro level. Finally, most of the SMEs, i.e. 138 or $53.1 \%$, had been operating for $7-10$ years.

\subsubsection{Measurement Model}

The psychological characteristic constructs in this study comprised four latent variables, namely need for achievement (with seven indicators, i.e., NA1, NA2, NA3, NA4, NA5, NA6, and NA7); risk taking (five indicators, RT1, RT2, RT3, RT4, and RT5); internal locus of control (five indicators, ILC1, ILC2, ILC3, ILC4, and ILC5); and independent motives (also five indicators, IM1, IM2, IM3, IM4, and IM5). Business performance consisted of six indicators, namely BP1, BP2, BP3, BP4, BP5, and BP6 to measure the concept. All the items were established as the composite indicator of the need for achievement, except NA1 in the EFA analysis and NA2 in the first order CFA. All the items in the other constructs, i.e., risk taking, internal locus of control, independent motives and business performance, were confirmed without a cut off during both the EFA and CFA. Therefore, CFA was conducted for the study measurement model. 
Based on Figure 1, the model adequately fits the integrated measurement model data, with $x^{2}=638.285 ; \mathrm{df}=276 ; \mathrm{p}=0.000 ; x^{2} / d f=2.313 ; \mathrm{CFI}=0.939>0.90 ; \mathrm{IFI}=$ $0.940>0.90$; and RMSEA $=0.071>0.08$.

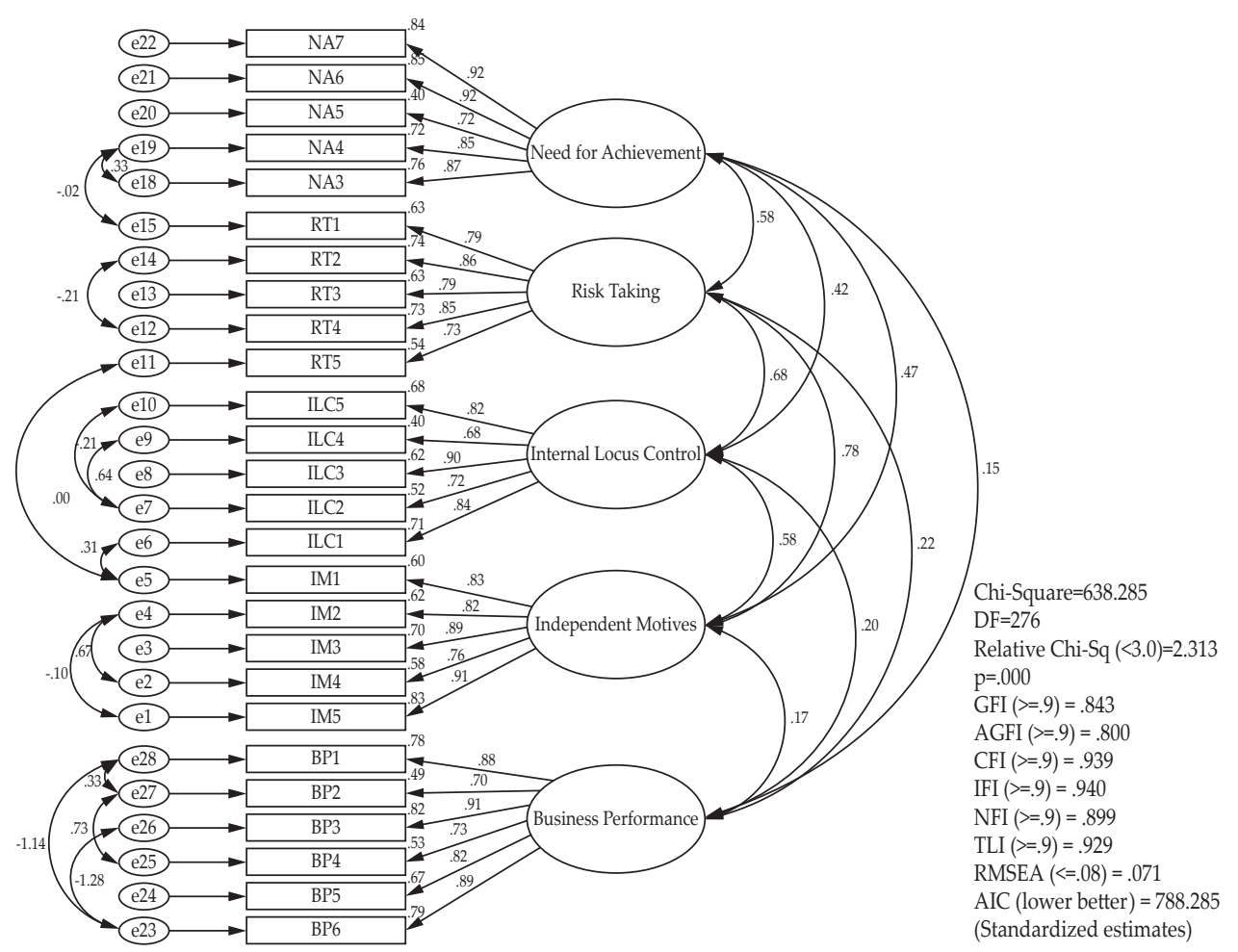

Figure 2.

Measurement Model

The construct reliability and discriminant validity of the model were computed, as shown in Table 2.

Table 2.

Reliability and Validity

\begin{tabular}{lccccccc}
\hline Factor & CR & AVE & NA & RT & ILC & IM & BP \\
\hline Need for Achievement (NA) & 0.932 & 0.734 & $\mathbf{0 . 8 5 7}$ & & & & \\
Risk Taking (RT) & 0.903 & 0.652 & 0.580 & $\mathbf{0 . 8 0 7}$ & & & \\
Internal Locus of Control (ILC) & 0.897 & 0.638 & 0.420 & 0.678 & $\mathbf{0 . 7 9 9}$ & & \\
Independent Motives (IM) & 0.914 & 0.682 & 0.468 & 0.782 & 0.584 & $\mathbf{0 . 8 2 6}$ & \\
Business Performance (BP) & 0.940 & 0.723 & 0.147 & 0.217 & 0.199 & 0.169 & $\mathbf{0 . 8 5 0}$ \\
\hline
\end{tabular}

According to Hair et al. (2010), the composite reliability (CR) and average variance extracted (AVE) for each construct should be above 0.7 and 0.5 respectively, with the CR higher than the AVE in order to achieve construct reliability. According 
to Table 2, each construct in this study exhibited a satisfactory level of research scale reliability, with factor loadings above 0.5 apart from item NA2, which was omitted since its factor loading was below 0.5 . Correspondingly, discriminant validity was also satisfactory, since the AVE square root of each construct was higher than each of the correlations between the constructs, and the correlations between the latent variables were below the threshold of 0.85 (Hair et al., 2010). Therefore, the model can be used for additional analysis and testing of the hypotheses.

\subsubsection{Results of the Direct Relationship between the Exogenous Variables and Business Performance}

Figure 2 shows the paths that connect the exogenous variables to the endogenous variable.

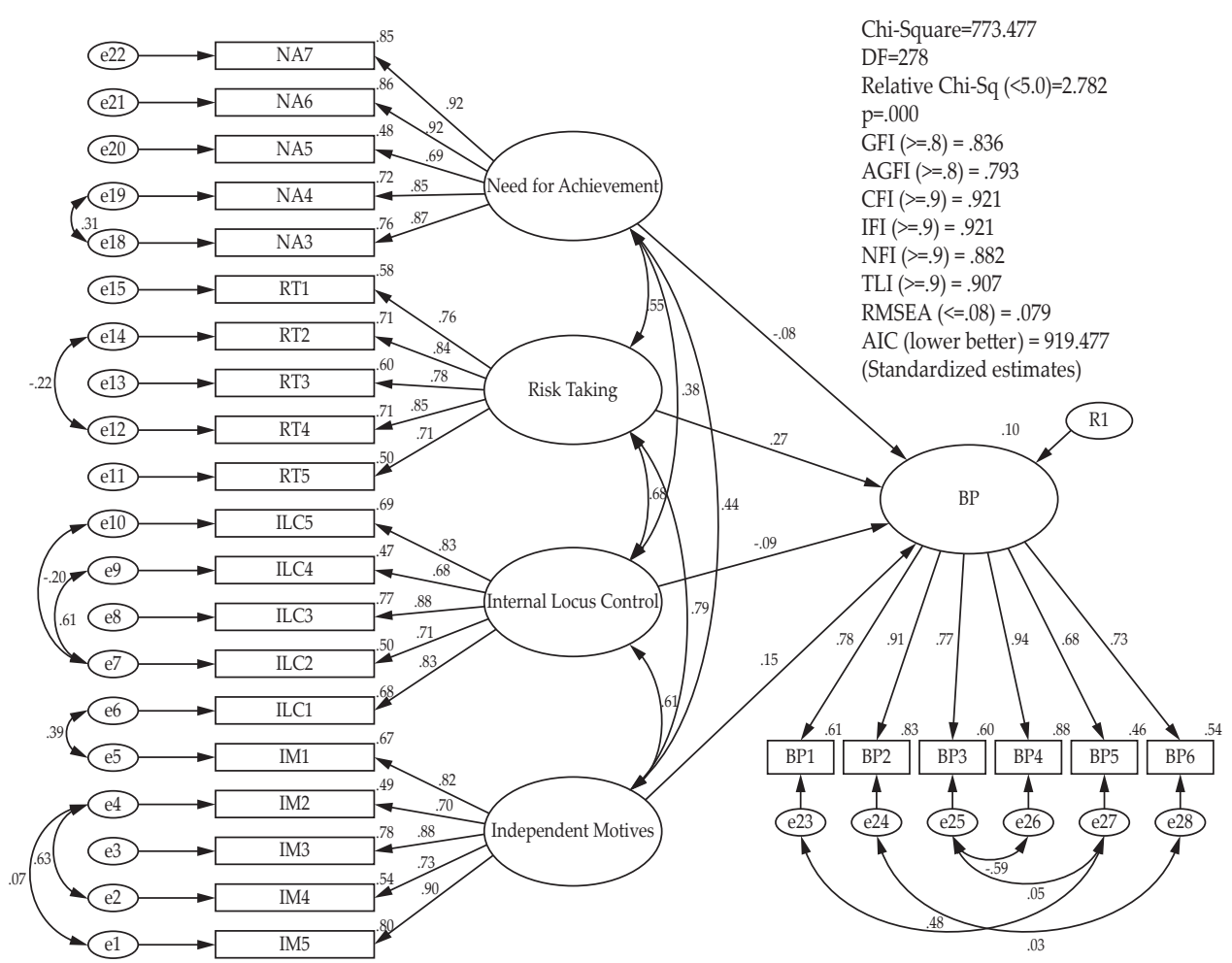

Figure 3.

Structural Model for the Dimensions of Psychological Characteristics and Business Performance

Figure 3 shows that the model adequately fits the structural model's data, with $x^{2}=782.040 ; \mathrm{df}=278 ; \mathrm{p}=0.000 ; x^{2} / d f=2.782<5 ; \mathrm{CFI}=0.921>0.90 ; \mathrm{IFI}=0.921>0.90$; $\mathrm{TLI}=0.907>0.90$ and RMSEA $=0.079<0.08$. According to Hair et al. (2010), the results demonstrate that a minimum of five goodness-of-fit indices were within the threshold value, such as RMSEA at 0.079. Accordingly, Table 3 shows the regression weights in the hypothesised path model. 
Table 3.

Regression Weights in the Hypothesised Path Model

\begin{tabular}{|c|c|c|c|c|c|c|c|}
\hline Path & & & $\begin{array}{c}\text { Standardised } \\
\text { Estimate }\end{array}$ & $\begin{array}{l}\text { Unstandardised } \\
\text { Estimate }\end{array}$ & S.E. & C.R. & $\mathbf{P}$ \\
\hline $\begin{array}{l}\text { Business } \\
\text { Performance }\end{array}$ & $<--$ & $\begin{array}{l}\text { Need for } \\
\text { Achievement }\end{array}$ & -.079 & -.057 & .054 & -1.071 & .284 \\
\hline $\begin{array}{l}\text { Business } \\
\text { Performance }\end{array}$ & $<--$ & Risk Taking & .271 & .246 & .123 & 2.002 & .045 \\
\hline $\begin{array}{l}\text { Business } \\
\text { Performance }\end{array}$ & $<---$ & $\begin{array}{l}\text { Internal Locus of } \\
\text { Control }\end{array}$ & -.091 & -.074 & .073 & -1.013 & .311 \\
\hline $\begin{array}{l}\text { Business } \\
\text { Performance }\end{array}$ & $<---$ & $\begin{array}{l}\text { Independent } \\
\text { Motives }\end{array}$ & .154 & .107 & .077 & 1.391 & .164 \\
\hline
\end{tabular}

Based on Table 3, risk taking is significant $(\beta=0.271, C R=2.002, p=0.045)$ at the 0.05 level, whereas need for achievement is not significant $(\beta=-0.079, C R=-1.071$, $p=0.284)$ at the 0.05 level. Similarly, internal locus of control $(\beta=-0.091, C R=-1.013$, $\mathrm{p}=0.311)$ and independent motives $(\beta=-0.154, \mathrm{CR}=-1.391, \mathrm{p}=0.164)$ are also not significant in this study. Therefore, only risk taking directly affects the business performance of Muslim women entrepreneurs in Sri Lanka.

\subsubsection{Moderating Effect of Educational Level}

The moderation effect of educational level on the relationship between the exogenous and endogenous variables amongst the Muslim women entrepreneurs in Sri Lanka was proposed to meet the fifth research objective. In the study, educational level was categorized into four groups, namely below G.C.E. $(\mathrm{O} / \mathrm{L})$, G.C.E. (O/L), G.C.E. (A/L), and degree or above. The results of these moderation effects are presented in Table 4.

Table 4.

Results of the Moderation Effect of Educational Level on the Relationship between Psychological Characteristics and Business Performance

\begin{tabular}{|c|c|c|c|c|c|c|}
\hline Path & & & Estimate & S.E. & C.R. & $\mathbf{P}$ \\
\hline Business Performance & $<--$ & $\begin{array}{l}\text { Psychological } \\
\text { Characteristics }\end{array}$ & & & & \\
\hline Below G.C.E. (O/L) & & & .121 & 0.118 & 1.024 & 0.306 \\
\hline G.C.E. $(\mathrm{O} / \mathrm{L})$ & & & 0.037 & 0.238 & 0.154 & 0.877 \\
\hline G.C.E. (A/L) & & & 0.177 & 0.136 & 1.302 & 0.193 \\
\hline Degree or above & & & 0.121 & 0.118 & 1.024 & 0.306 \\
\hline
\end{tabular}

Based on Table 4, it can be seen that the p-values for all the educational level groups were not significant in the relationship between psychological characteristics and business performance at the 0.05 level of significance; that is, the below G.C.E educational level group $(\beta=0.121, \mathrm{p}=0.306)$; G.C.E. $(\mathrm{O} / \mathrm{L})$ group $(\beta=0.037, \mathrm{p}=0.877)$; G.C.E. $(\mathrm{A} / \mathrm{L})$ group $(\beta=0.177, \mathrm{p}=0.193)$ and degree or above level 
group $(\beta=0.121, p=0.306)$. Since the $p$-values for all groups were higher than 0.05 $(\mathrm{p}>0.05)$, educational level did not significantly moderate the relationship between psychological characteristics and business performance.

Another significant finding in relation to the educational level of the Muslim women entrepreneurs is that most of them (48.6\%) only possessed G.C.E. (O/L) as their highest qualification. This corresponds to their age and the tradition amongst Muslim families two or three decades ago to prefer their daughters not to pursue higher studies and instead to choose early marriage; $88.8 \%$ of the respondents are or were once married.

\subsection{Discussion}

Four hypotheses were developed to achieve the research objective of the study. Hypothesis 1 examines the effect of the need for achievement on the business performance of Muslim women entrepreneurs in Sri Lanka's Eastern province. The structural model analysis showed that such a need does not have a significant effect on business performance, as the p-value is higher than 0.05, i.e., 0.284 with $\beta=-0.079$ and $C R=-1.071$. This indicates that the need for achievement has no direct and significant relationship with business performance in the context of this study. Therefore, Hypothesis 1 is rejected. According to Fuad \& Bohari (2011) and Rashid et al. (2015), the need for achievement has a significant positive effect on the business performance of Malay and Indonesian women entrepreneurs (Anggadwita \& Dhewanto, 2016). Furthermore, Rani \& Hashim (2017) found that the need for achievement had a positive significant relationship with business performance. However, the need did not affect business performance in this study. This may indicate that Muslim women entrepreneurs in Sri Lanka may lack the readiness to achieve anything imperative in their life and have fewer goals to generate new business prospects. According to the annual report of the Chamber of Commerce in Sri Lanka of 2017, only 7\% of Muslim women entrepreneurs owned/ managed businesses in the country, which also indicates that they are underutilized compared to their male counterparts, who make up the largest proportion of business owners (93). This implies that Muslim women entrepreneurs lack the need for achievement.

Hypothesis 2 examines the effect of risk taking on the business performance of the Muslim women entrepreneurs studied. The structural model analysis shows that risk taking has a significant effect on business performance $(\beta=0.271, p=0.045<$ 0.05). This indicates that it is directly correlated to business performance, so Hypothesis 2 is confirmed. The Islamic perspective urges all individuals to strive for efficacy (Suah Ar-Rahd, Versus, 11). However, Sri Lankan Muslim women entrepreneurs are risk taking. Similarly, Fuad \& Bohari (2011) specify that working hard and maintaining a high level of confidence and trust in their ability to control their lives can lead to business success.

Hypothesis 3 examines the effect of the internal locus of control on the business performance of the women entrepreneurs. The structural model analysis shows that it has a significant effect on business performance $(\beta=-0.091, p=0.311>0.05)$, which suggests that the internal locus of control and business performance do not have a direct relationship in this study. Therefore, Hypothesis 3 is rejected. Anggadwita \& Dhewanto (2016) found that locus did have an influence on 
Muslim women entrepreneurs in Indonesia. However, it is not significant in the relationship with business performance in this study. Sri Lankan Muslim women entrepreneurs may have the certainty that their success is contingent mostly on fate rather than their own determination.

Finally, Hypothesis 4 examines the effect of independent motives on business performance. The structural model analysis shows that these have no significant effect $(\beta=0.154, p=0.164>0.05)$. This indicates that independent motives and business performance are not directly correlated in this study. Therefore, Hypothesis 4 is rejected. In terms of independent motives, Maden (2015) stresses that being independent in making one's own decisions and in one's activities is one of the foremost factors among Turkish women entrepreneurs. According to Chowdhury, Yeasmin, \& Ahmed (2018), women typically have limited roles in business or decision-making processes. Independent motives are not significantly correlated with the business performance of Muslim women entrepreneurs in the context of this study. Therefore, in the psychological characteristic constructs, risk taking is the only one predicted to enhance the business performance, while educational level did not moderate the relationship between the psychological characteristics and business performance of Muslim women entrepreneurs in Sri Lanka.

\section{CONCLUSION AND RECOMMENDATIONS}

\subsection{Conclusion}

The study has examined the effect of psychological characteristics on the business performance of Muslim women entrepreneurs in Sri Lanka using a structured questionnaire. It has achieved all its research objectives of determining the effects of the psychological factors of need for achievement, risk taking, internal locus of control, and independent motives on the business performance of Muslim women entrepreneurs. In addition, the moderation effect of educational level between the variables was established. Furthermore, the study has addressed an important research gap concerning Muslim women entrepreneurs, which has to date not been comprehensively investigated in Sri Lanka together with the moderation effect. The use of advanced statistical tools such as SEM further contributed to the value of the study. The findings show that only risk taking significantly affects the business performance of Muslim women entrepreneurs in Sri Lanka.

From their childhood onwards, Muslim women are reliant on their male counterparts. This could be the reason why the factors of need for achievement, internal locus of control and independent motives have no statistically significant influence on their business performance. However, risk taking is shown to directly affect such performance. For Muslim women, there are unique challenges, such as barriers to leaving home alone, mixing with counterparts, and their lack of willingness to access capital and resource due to the traditions and values adhered to in Muslim societies. Therefore, psychological characteristics have a significant effect on Sri Lankan Muslim women entrepreneurs' business performance.

Furthermore, educational level did not moderate the relationships between psychological characteristics and business performance. Whilst psychological characteristics are understood from the standpoint of family traditions and 
religion, they convey the message that anyone could be a risk taker, irrespective of educational level.

\subsection{Recommendations}

The study findings could provide valuable guidelines to budding Muslim women entrepreneurs on developing their strengths and overcoming their weaknesses in the business field. The findings also offer significant insights into the roles of family members, spouses and the society in general in supporting the women.

Among the psychological characteristics, only risk taking was shown to have a significant impact on business performance. Therefore, the government and other non-governmental agencies could utilize the findings to develop policies that could facilitate the growth of Muslim women entrepreneurs, such as the provision of training and capacity-building programs to enhance their risk-taking propensity.

To act upon these findings, it is also recommended that policy makers and regulators promote the importance of entrepreneurship in higher learning institutions in Sri Lanka. This would be one effective way of reducing the social stigma faced by Muslim women entrepreneurs, although the efforts may take some time to come to fruition.

Moreover, since the study only focuses on Muslim women entrepreneurs under the District Chamber of Commerce and Industry in the Sri Lankan Eastern province, researchers and academics could expand the investigation by sampling Muslim women entrepreneurs who are not registered under the District Chamber of Commerce and Industry in the same Province and further extend to other provinces in Sri Lanka and also across countries.

\section{REFERENCES}

Abdullah, S. A. C., \& Sahad, M. N. (2016). Integrated marketing communication: A spiritual and an ethical Islamic perspective. International Journal of Islamic Marketing and Branding, 1(4), 305-320.

Ahmad, M., Ahmad, E., Kahat, M. B. H., \& Mutaza, G. (2012). New determination of factors affecting the growth of small and medium enterprises in Pakistan. Interdisciplinary Journal of Contemporary Research in Business, 4(6), 513-530.

Akhter, M. N., \& Sobhani, F. A. (2016). Entrepreneurship for women in Islam: An institutional perspective. Daffodil International University Journal of Business and Economics, 10(2), 97-109.

Al-Quran Surah Ar-Rad: 11.

Al-Quran Surah An-Nisha:29.

Al-Sadi. R., Belwal, R., \& Al-Badi, R. (2011). Women entrepreneurship in the AlBatinah region of Oman: An identification for barriers. Journal of International Women Studies, 12(3), 58-75.

Anggadwita, G., \& Dhewanto, W. (2016). The influence of personal attitude and social perception on women entrepreneurial intentions in micro and small enterprises in Indonesia. International Journal of Entrepreneurship and Small Business, 27(2/3), 131-148. 
Anggadwita, G., Luturlean, B. S., Ramadani, V., \& Ratten, V. (2017). Sociocultural environments and emerging economy entrepreneurship: Women entrepreneurs in Indonesia. Journal of Entrepreneurship in Emerging Economies, 9(1), 85-96.

Anggadwita, G., Mulyaningsih, H. D., Ramadani, V., \& Arwiyah, M. Y. (2015). Women entrepreneurship in Islamic perspective: A driver for social change. International Journal of Business and Globalization, 15(3), 389-404.

Annual Report, Department of Census and Statistics (DCS), Sri Lanka (2017).

Asad Sadi, M., \& Al-Ghazali, B. M. (2010). Doing business with impudence: A focus on women entrepreneurship in Saudi Arabia. African Journal of Business Management, 4(1), 1-11.

Azam Roomi, M., \& Harrison, P. (2010). Behind the veil: Women-only entrepreneurship training in Pakistan. International Journal of Gender and Entrepreneurship, 2(2), 150-172.

Baluku, M. M., Kikooma, J. F., Bantu E., \& Otto, K. (2018). Psychological capital and entrepreneurial outcomes: The motivating role of social competences of owners of micro-enterprises in East Africa. Journal of Global Entrepreneurship Research, 8(26), 1-25.

Baluku, M. M., Kikooma, J. F., Bantu E., Onderi, P., \& Otto, K. (2019). Impact of personal cultural orientations and cultural intelligence on subjective success in self-employment in multi-ethnic societies. Journal of Global Entrepreneurship Research, 9(8), 1-22.

Baron, R.A., Franklin, R. J., \& Hmieleski, K.M. (2016). Why entrepreneurs often experience low, not high level of stress: The joint effects of selection and psychological capital. Journal of Management, 42(3), 742-768.

Byrne, B. M. (2016). Structural equation modeling with AMOS: Basic concepts, applications, and programming, $3^{\text {rd }}$ ed., New York NA: Routledge.

Chowdhury, T. Y., Yeasmin, A., \& Ahmed, Z. (2018). Perception of women entrepreneurs to assessing bank credit. Journal of Global Entrepreneurship Research, 8(32), 1-16.

Dechant, K. \& Al Lamky, A. (2005). Toward an understanding of Arab women entrepreneurs in Bahrain and Oman. Journal of Development Entrepreneurship, 10(2), 123-140.

Dharmaratne, K. L. B. G. (2012). Impact of individual factors on the business performance of women entrepreneurs in Sri Lanka. Sabaragamuwa University Journal, 11(1), 139-165.

Faizal, P. R. M., Ridhwan, A. H. M., \& Kalsom, A. W. (2013). The entrepreneurs' characteristics from Al-Quran and Al-Hadis. International Journal of Trade, Economics, and Finance, 4(4), 191-196.

Fernando, A. K. A. (2006). Entrepreneurship and exploration of barriers to learning and practicing entrepreneurship. In Proceedings of the Third International Conference on Business Management. University of Sri Jayawardenapura, Colombo, 45-53.

Fuad, N., \& Bohari, A. M. (2011). Malay women entrepreneurs in the small and medium sized ICT related business: A study on need for achievement. International Journal of Business and Social Science, 2(13), 272-278. 
Gupta, P. D., Guha, S., \& Krishnaswami, S. S. (2013). Firm growth and its determinants. Journal of Innovation and Entrepreneurship, 2(15), 1-15.

Gustomo, A., Ghina, A., Anggadwita, G., \& Herliana, S. (2019). Exploring entrepreneurial competencies in identifying ideas and opportunities, managing resources, and taking action: Evidence from small catering business owners in Bandung, Indonesia. Journal of Foodservice Business Research, 22(6), 509-528.

Hair, J. F., Black, W. C., Barry, B. J., \& Anderson, R. E. (2010). Multivariate data analysis $7^{\text {th }} \mathrm{Ed}$. New Jersey: Prentice Hall.

Hammawa, Y. M., \& Norashidah, B. H. (2016). Women entrepreneurs' spirituality in business based on Al-Quran and Sunnah: An ethico-metaphysical dimension. IOSR Journal of Business and Management, 18(6), 37-40.

Hwang, H., Malhotra, N. K., Kim, Y., Tomiuk, M. A., \& Hong, S. (2010). A comparative study on parameter recovery of three approaches to structural equation modeling. Journal of Marketing Research, 47(4), 699-712.

Ibidunni, A.S., Ibidunni, O.M., Olukundar, M.A., Oke, O.A., Ayeni, A.W., Falola, H.O., Salautio, S.O.P. \& Borishade, T.T. (2018). Examining the moderating effect of entrepreneurs' demographic characteristics on strategic entrepreneurial orientation and competitiveness of SMEs. Journal of Entrepreneurship Education, 21(1), 1-8.

Ilhaamie A. G. A. (2017). Muslim women entrepreneurs' motivation in SMEs: A quantitative study in Asia Pacific countries. Asian Economic and Financial Review, 7(1), 27-42.

Ilhaamie. A. G. A., Arni, B. S., Rosmawani, C. H., \& Al-Banna, M. H. (2014). Challenges of Muslim women entrepreneurship in Malaysian SMEs. International Journal of Innovation, Management and Technology, 5(6), 428-433.

Islam, Md. A., Khan, M. A., Obaidullah, A. Z. M., \& Alam, M. S. (2011). Effect of entrepreneur and firm characteristics on the business success of small and medium enterprises (SMEs) in Bangladesh. International Journal of Business and Management, 6(3), 289-299.

Itani, H., Sidani, M. Y., \& Balbaki, I. (2009). UAE female entrepreneurs: Motivations and frustrations. Equality, Diversity, and Inclusion: An International Journal, 30(5), 409-424.

Kargwell, S. A. (2012). A comparative study on gender and entrepreneurship development: Still a male's world within UAE cultural context. International Journal of Business and Social Science, 3(6), 44-55.

Lerner M., Brush C. \& Hisrich, R. (1997). Israeli women entrepreneurs: An examination of factors affecting performance. Journal of Business Venturing, 12(4), 315-339.

Machado, H. P. V. (2016). Growth of small businesses: A literature review and perspective of studies. Gest. Prod, 23(2), 419-432.

Machmud, A., \& Ahman, E. (2019). Effect of Entrepreneur psychological capital and human resources on the performance of the catering industry in Indonesia. Journal of Entrepreneurship Education, 22(1), 1-7.

Machmud, A., \& Hidayat, Y. M. (2020). Characteristics of Islamic entrepreneurship and the business success of SMEs in Indonesia. Journal of Entrepreneurship Education, 23(2), 1-16. 
Maden, C. (2015). A gendered lens on entrepreneurship: Women entrepreneurship in Turkey. Gender in Management: An International Journal, 30(4), 312-331.

McIntosh, J. C., \& Islam, S. (2010). Beyond the veil: The influence of Islam on female entrepreneurship in a conservative Muslim context. International Management Review, 6(1), 103-109.

Mustapha, M., \& Subramaniam P. A/P. (2016). Challenges and success factors of female entrepreneurs: Evidence from a developing country. International Review of Management \& Marketing, 6(S4), 224-231.

Panda, S. (2018). Constrained faced by women entrepreneurs in developing countries: Review and ranking. Gender in Management, 33(4), 315-331.

Perera, T., \& Budhadhasa, S. (1992). Characteristics of Sri Lankan entrepreneurs: How valid is the Schumpeter model? In G. Nanayakara (Ed.). The Emerging Economic Order in Sri Lanka Managerial Leadership. Postgraduate Institute of Management, Colombo, 83-92.

Ranasinghe, S. B. (2008). Factors contributing to the success of women entrepreneurs in Sri Lanka. Sri Lanka Journal of Advanced Social Studies, 1(2), 85-110.

Rani, S. H. Abd., \& Hashim, N. (2017). Factors that influence women entrepreneurial success in Malaysia: A conceptual framework. International Journal of Research in Business Studies and Management, 4(1), 16-25.

Rashid, K. M., Ngah, H. C., Mohamed, Z., \& Mansor, N. (2015). Success factors among women entrepreneurs in Malaysia. International Academic Research Journal of Business and Technology, 1(2), 28-36.

Rekarti, E., Bahari, Z., Zahari, N. M., Doktoralina, C. M., \& Ilias, N. A. (2019). The sustainability of Muslim women entrepreneurs: A case study in Malaysia. International Journal of Financial Research, 10(5), 430-439.

Schumpeter, J. A., Clemence, R. V., \& Swedberg, R. (2017). Essays: On entrepreneurs' innovations, business cycles, and the evolution of Capitalism. New York: Routledge.

Tri Ramdhani, A. D., \& Anggadwita, G. (2016). Identifications of Psychological Characteristics of Successful Muslim Women Entrepreneur in Islamic Perspective. Retrieved from http:///www.library.telkomuniverity.ac.id/pustaka/files.

Ullah, Md. M., Mahmud, T., \& Yousuf, F. (2013). Women entrepreneurship: Islamic perspective. European Journal of Business Management (EJBM) Special Issue on Islamic Management and Business, 5(11), 253-269.

Walker, I., \& Brown, A. (2004). What success factors are important to small business owners. International Small Business Journal, 22(6), 577-594.

Yadev, M. P. (2015). Model of entrepreneurial success: A review of research agenda. Journal of Advanced Academic Research, 2(1), 40-50.

Zulkiffli, S. N. A. (2014). Business performance of SMEs: Subjective or objective measures? Review of Integrative Business \& Economic Research, 3(1), 391-401. 